\title{
Feeding behavior of cockatiels in captivity
}

\section{Comportamento alimentar de calopsitas em ambiente artificial}

\author{
Priscila Pimentel Freitas ${ }^{1}$; Vanair Carlos Paz $^{2}$; Rodrigo Diana Navarro ${ }^{1}$ \\ ${ }^{1}$ Universidade de Brasília, Faculdade de Agronomia e Medicina Veterinária, Brasília - DF, Brazil \\ ${ }^{2}$ Criadouro Vanair aves, Planaltina - DF, Brazil
}

\begin{abstract}
In nature, cockatiel (Nymphicus hollandicus) feed consists of a huge variety of seeds, fruits, flowers, leaves, and insects. In captivity, their feed is generally poor, as many breeders offer only a mixture of seeds as food, leading to nutrient deficiency and even obesity. This paper presents a study on cockatiel feeding behavior in artificial environments at different stages of development (growth, maintenance, and reproduction), to evaluate their preference from the offer of six different food types (sunflower seed, oats, millet, rice, ration, and a cornmeal based feed or farinhada), and an analysis of their preferences for locations in the cage. No significant differences were observed about the final weight of the birds during the stages of development. Consumption of millet seeds was significantly higher in the growth stage, but at this stage, the birds showed a preference for oats. On the other hand, at the reproduction and maintenance stages, they showed a preference for sunflower seeds. The birds in the reproduction stage were the ones that visited the nest, and the nest grid, the most. Among all the cage locations, all birds showed a preference for the perches.
\end{abstract}

Keywords: Feeding. Behavior. Parrots. Nymphicus hollandicus.

\section{RESUMO}

Na natureza a calopsita (Nymphicus hollandicus) tem a sua alimentação composta por uma enorme variedade de sementes, frutos, flores, folhas e insetos. Em cativeiro a sua alimentação geralmente é deficiente, pois muitos criadores oferecem apenas misturas de sementes como alimento, causando deficiência de nutrientes e até mesmo obesidade. Neste trabalho foi realizado um estudo sobre o comportamento alimentar de calopsitas em ambiente artificial em diferentes fases de desenvolvimento (crescimento, mantença e reprodução) e uma análise de uso do espaço pelas aves dentro da gaiola, com o objetivo de avaliar a preferência das aves a partir da oferta de seis diferentes tipos de alimentos (sementes de girassol, aveia, painço, arroz, ração e farinhada) e a preferência das mesmas pelos locais na gaiola. Não foram observadas diferenças significativas entre as fases de desenvolvimento ao que se diz respeito ao peso final dos animais. $\mathrm{O}$ consumo de sementes de painço foi significativamente maior na fase de crescimento, mas o alimento preferido nessa fase foi a aveia. Já nas fases de reprodução e mantença a preferência foi pela semente de girassol. As aves na fase de reprodução foram as que mais visitaram o ninho e a grade do ninho. O local das gaiolas preferido por todas as aves foram os poleiros.

Palavras-chave: Alimentação. Comportamento. Papagaios. Nymphicus hollandicus. 


\section{Correspondence to:}

Rodrigo Diana Navarro

Universidade de Brasília, Faculdade de Agronomia e Medicina Veterinária

Campus Universitário Darcy Ribeiro, ICC Sul - Asa Norte

CEP: 70910-970, Brasília - DF, Brazil

e-mail: navarrounb@gmail.com

Received: March 31, 2020

Approved: November 6, 2020

How to cite: Freitas PP, Paz VC, Navarro RD. Feeding behavior of cockatiels in captivity. Braz J Vet Res Anim Sci. 2020;57(4):e168320. https://doi.org/10.11606/issn.16784456.bjvras.2020.168320

\section{Introduction}

Psittaciformes are extremely popular because of their sociable nature, intelligence, coloration, and ability to imitate sounds, which makes them the birds most frequently kept as pets in the world (Cubas et al., 2014). According to Forshaw (1973), the cockatiels (Nymphicus hollandicus) are included in the Order of Psittaciformes, Family Cacatuidae, and species Nymphicus hollandicus. They were first described by Kerr in 1792 .

Originating from the interior of Australia (Forshaw, 2010) cockatiels have elongated lines, measure around 30 centimeters in length, with adults weighing from 80 to 120 grams (Roudybush \& Grau, 1986), and present an erect crest at the top of the head with different fluffs. These birds can exhibit different color patterns, among them Cinnamon, Pearl, Albino, Harlequin, Whiteface, Lutino, and Common.

Since 1998, the Brazilian Institute of Environment and Renewable Natural Resources (IBAMA) has classified cockatiels as belonging to the domestic fauna, which means cockatiel breeding becamelegalized in captivity, and its commercialization as pets was authorized. Thus, the search for these animals increased because of their aesthetic characteristics, cheerful temperament, and the ability to imitate sounds.

Psittaciformes, in general, are monogamous. In Brazil, its reproductive period occurs in spring and summer, with some variations (Cubas et al., 2014). These birds reach sexual maturity at around 12 months of age and usually lay from three to seven eggs, one per day or every other day, and both the male and the female prepare the nest and take turns incubating the eggs (Torloni, 2001; Ubuka \& Bentley, 2011).

Most free-living psittaciformes have plant-based nutrition (Harcourt-Brown, 2003; Morton, 1985). Cockatiels were classified as a granivorous bird (Koutsos et al., 2001a) and in natural conditions, its food consists of a wide variety of seeds, fruits, leaves, flowers, and insects. They usually live in desert regions, even traveling for many miles, in flocks, looking for food near rivers. Unlike most psittaciformes, they carry out most of their feeding on the ground (Torloni, 2001). In periods of shortage, they obtain an incomplete dietary balance for their nutritional requirements (Machado \& Saad, 2000).

In captivity, energy demands are substantially reduced relative to free-living needs (Carciofi, 2000). Many breeders offer seed mixtures in addition to other foods, often in excess, and the birds, which selectively ingest the most palatable food they find, are unable to balance their diet, which can lead to obesity, reproductive problems, and the nutritional deficiency (Carciofi \& Saad, 2001; Carciofi et al., 2003; Mendes, 1999).

Granivorous birds, such as cockatiels, select foods low in protein and high in carbohydrates. These species have low nutritional requirements for amino acids and appear to be able to conserve amino acids by regulating their catabolism (Koutsos et al., 2001b). According to Harper \& Skinner (1998), the energy required for maintenance (MER) of a cockatiel is $29 \mathrm{Kcal}(120 \mathrm{~kJ})$ per day. For the females at the reproduction stage, the energy requirements increase during the pre-posture and posture phases, more significantly in the posture phase. But the highest MER phase for any bird is the growth phase.

Harper \& Skinner (1998) report that the required amount of protein in the diet for small psittaciformes is from 10 to $14 \%$, containing the appropriate amino acid profile (essential amino acids). Koutsos et al. (2001b) observed that the protein requirement for cockatiels and parakeets was probably $11 \%$ of the diet or less. For the birds in the growth period, the percentage of protein in the diet should be $20 \%$ ( $1 \%$ methionine + cysteine, $1.5 \%$ lysine) to achieve maximum growth (Koutsos et al., 2001b).

The only essential fatty acid for which the dietary requirement was observed in poultry is linoleic acid. The amount of linoleic acid needed to avoid signs of deficiency is quite low, about $1 \%$ of the diet. But an inadequate supply of this nutrient causes symptoms of deficiency such as increased water intake (a classical sign of deficiency). For birds that have diets containing seed mixtures, this deficiency is difficult to observe (Harper \& Skinner, 1998).

One of the most important minerals in the birds' diets is calcium. In general, the requirement for this mineral in the maintenance diet is low. Experimental and clinical evidence indicates that a diet based exclusively on seeds can lead to calcium deficiency and that the need for this mineral 
is above $0.05 \%$. For cockatiels and parakeets, the calcium requirement becomes $0.35-0.85 \%$ (Koutsos et al., 2001a).

\section{Objectives}

This investigation evaluated the eating behavior, and location preferences, of cockatiels in artificial environments at different development stages (growth, maintenance, and reproduction).

\section{Material and Methods}

The work was developed in the Vanair Aves Breeder, located in Planaltina, Distrito Federal, Brazil (latitude $15^{\circ} 38^{\prime} 25^{\prime \prime} \mathrm{S}$ and longitude $47^{\circ} 41^{\prime} 7^{\prime \prime} \mathrm{W}$ ). The total area of the nursery is $5,000 \mathrm{~m}^{2}$, most of which is outdoors. The mean temperature during the data collection period was $29^{\circ} \mathrm{C} \pm 4^{\circ} \mathrm{C}$ (according to data from the National Institute of Meteorology). All procedures were per the research (Martins et al., 2019). Ibama authorization number 9999.7575/2013-DF.

Eighteen cockatiels were used, one pair per cage. Cockatiels were young for 10 months and adults for one year. The experiment was carried out in a completely randomized design, with three couples for each of the three different stages: reproduction (stage 1), maintenance (stage 2), and growth (stage 3). Feeding behavior was observed from September to December 2015, with an average of 45 hours of sampling effort and a total of 1,350 records. The method of data annotation was the focal animal with instantaneous recording. The animals were observed twice a week in the afternoon (between 15:00 and 17:00), with intervals of two minutes between each recording, for one to two hours per day (records of 31 h-1) (Altmann, 1974). The recordings were performed immediately after the replacement of the food. All birds came from the same breeder, were not used in other experiments, and the breeding pairs were formed before the experiment. All cages had a nest.

The birds were weighed and measured (total length from the beak to the tip of the tail) at the beginning of the study (September 14, 2015). The weighing procedure was repeated twice during the data collection period (October 7 and November $14,2015)$ and one last time after collection (December 24 , 2015), totaling four measurements. The length measurement was performed at the beginning and the end of the study, along with the first and last weighing (Table 1), The birds were weighed twice to avoid stress. The body score of the birds was classified as good, according to visual assessment of fat deposition in the chest (Cubas et al., 2014).

Each pair of Nymphicus hollandicus was kept in a cage measuring $0.5 \mathrm{~m} \times 0.5 \mathrm{~m} \times 0.5 \mathrm{~m}$, inside a masonry shed with two metal mesh walls with plastic canvas curtains, and a clay tile roof with some transparent acrylic tiles for better illumination. The locations inside the cage are detailed in Table 2. The foods offered were: sunflower seeds with bran; the seed of millet with bran; seeds of oats; rice with bran; ration for small birds (BioTron ${ }^{\circ}$ fruits and cereals); farinhada (corn-based meal, dry-mashed diet) - breeder's blend (corn flakes, powdered egg, multivitamin, a powdered supplement of phosphorus, potassium, calcium and other minerals). Solid calcium supplementation was added to all cages.

After data collection, the statistical analysis of daily consumption, behavioral data, and biometric data was performed via a one-way ANOVA analysis of variance by the $\mathrm{PAST}^{\oplus}$ program (Hammer \& Harper, 2001).

Once a day in the afternoon, every cage received $42 \mathrm{~g}$ of each food (seeds, ration, and farinhada), each in a different feeder to better assess the birds' feeding behavior, along with $160 \mathrm{~mL}$ of drinking water. The remaining food within the feeders was weighed individually for daily consumption data collection and then refilled. Food that fell to the bottom of the cage during feeding was not weighed, and so was not accounted for.

Before consumption, the food samples were analyzed in the Animal Nutrition Laboratory of the Pioneer Union of Social Integration (UPIS) to assess their composition, regarding the amount of dry matter, protein, total fat (ethereal extract), and mineral matter according to procedures described by Silva (1990). The results are presented in Table 3.

\section{Results}

All subjects remained healthy and had a good body score. The mean temperature during the data collection period was $29^{\circ} \mathrm{C} \pm 4^{\circ} \mathrm{C}$ (according to data from the National Institute of Meteorology).

Table 1 - Mean initial length and weight of Nymphicus hollandicus at different development stages followed by the corresponding standard deviation

\begin{tabular}{|c|c|c|c|c|}
\hline & \multicolumn{2}{|c|}{ Length } & \multicolumn{2}{|c|}{ Weight } \\
\hline & Females & Males & Females & Males \\
\hline Reproduction & $34.3 \pm 0.6 a$ & $35 \pm 1 a$ & $119.3 \pm 5.7 a$ & $107.3 \pm 21.9 a$ \\
\hline Maintenance & $34.3 \pm 1.15 a$ & $35 \pm 2.65 a$ & $133 \pm 1.73 b$ & $128.3 \pm 18.9 a$ \\
\hline Growth & $25.3 \pm 5.03 b$ & $28.7 \pm 6.8 a$ & $115.7 \pm 3.2 b$ & $108.3 \pm 9.9^{a}$ \\
\hline
\end{tabular}

Averages in the same column followed by different letters differ at the $5 \%$ level of significance. 
Table 2 - Description of locations within the cage where Nymphicus hollandicus were maintained

\begin{tabular}{ccc}
\hline Acronym & Location & Description \\
\hline GP & Door Grille & Steel wire structure $3.5 \mathrm{~mm}$ in diameter, white $(0.5 \times 0.5 \mathrm{~m}) ; 1.6 \mathrm{~cm}$ spacing between bars; guillotine \\
type door $(20 \mathrm{~cm} \times 25 \mathrm{~cm})$.
\end{tabular}

Table 3 - Results of the bromatological analysis of the foods offered to the Nymphicus hollandicus during the observation period. Results concern dry matter

\begin{tabular}{|c|c|c|c|c|}
\hline Sample & Dry Matter $105^{\circ} \mathrm{C}$ DM (\%) & Mineral Matter MM (\%) & Ethereal Extract EE (\%) & Total Protein TP (\%) \\
\hline Rice $^{(1)}$ & $88.84 \pm \%$ & $4.71 \%$ & $0.92 \%$ & $7.65 \%$ \\
\hline Millet $^{(1)}$ & $89.07 \%$ & $1.97 \%$ & $0.52 \%$ & $14.53 \%$ \\
\hline Oats $^{(1)}$ & $88.65 \%$ & $1.69 \%$ & $1.78 \%$ & $16.80 \%$ \\
\hline Sunflower $r^{(1)}$ & $91.66 \%$ & $2.23 \%$ & $3.71 \%$ & $15.05 \%$ \\
\hline Farinhada $^{(2)}$ & $89.88 \%$ & $4.15 \%$ & $1.07 \%$ & $14.07 \%$ \\
\hline Rations ${ }^{(3)}$ & $89.12 \%$ & $7.13 \%$ & $2.30 \%$ & $17.25 \%$ \\
\hline
\end{tabular}

Analysis carried out at the UPIS Food Analysis Laboratory, Campus II, Planaltina, DF. ${ }^{(1)}$ Seed with bran; ${ }^{(2)}$ Ingredients present: Corn flakes, egg powder, multivitamin, a powdered supplement of phosphorus, potassium, calcium, and other minerals; ${ }^{(3)}$ Ration for small birds - BioTron $®$ fruits and cereals.

Table 4 - Average weights (g) of Nymphicus hollandicus were done before, during, and after the observations of each development stage, followed by the corresponding standard deviation

\begin{tabular}{ccc}
\hline Stages & Female & Male \\
\hline Reproduction & $118 \mathrm{a}$ & $107.5 \mathrm{a}$ \\
Maintenance & $115.6 \mathrm{a}$ & $125.3 \mathrm{a}$ \\
Growth & $115.4 \mathrm{a}$ & $106.25 \mathrm{a}$ \\
\hline Means followed by different letters differ at the $5 \%$ level of significance.
\end{tabular}

Table 5 - Mean initial and final length $(\mathrm{cm})$ of the Nymphicus hollandicus on each development stage, followed by the corresponding standard deviation

\begin{tabular}{ccc}
\hline Stages & Female & Male \\
\hline Reproduction & $34.3-35 \pm 34.7 \mathrm{a}$ & $35-35.7 \pm 35.3 \mathrm{a}$ \\
Maintenance & $34.3-35 \pm 34.7 \mathrm{a}$ & $35-35 \pm 35 \mathrm{a}$ \\
Growth & $25.3-31.3 \pm 28.3 \mathrm{~b}$ & $28.7-34.3 \pm 31.5 \mathrm{a}$ \\
\hline
\end{tabular}

Averages in the same column followed by different letters differ at the $5 \%$ level of significance.

Weight variations during the experiment are shown in Table 4. No bird displayed significant weight variation $(\mathrm{p}<0.05)$.
There was no significant length variation on birds in the stages of reproduction or maintenance, or males in the growth stage. There was a significant difference in length for females in the growth stage (Table 5).

There was no significant difference in daily food consumption on any stage, except for millet $(p<0.05)$ in Table 6.

The birds in the growth stage visited the rice, millet, oats, and sunflower seed feeders more often than the birds at other stages. The frequency of visits to the "farinhada" feeder was not significantly different between stages. The birds in the reproduction and growth stages showed a significant difference in the frequency with which they visited the ration feeder in Table 7.

From the analysis of bird location preference data (Table 8), we found that the birds of the reproduction stage frequented the door grid fewer times $(\mathrm{p}<0.05)$ compared to the birds of other stages of development. Likewise, they obtained a lower frequency of visits to the partition grid and the upper grid. The nest grid was visited more frequently by 
Table 6 - Average daily consumption (g) of the couple of Nymphicus hollandicus based on the foods offered

\begin{tabular}{ccccccc}
\hline & Rice & Millet & Oats & Sunflower & Farinhada & Ration \\
\hline Reproduction & $6.53 \mathrm{a}$ & $6.03 \mathrm{a}$ & $7.11 \mathrm{a}$ & $7.50 \mathrm{a}$ & $2.70 \mathrm{a}$ & $4.70 \mathrm{a}$ \\
Maintenance & $6.26 \mathrm{a}$ & $7.70 \mathrm{a}$ & $8.70 \mathrm{a}$ & $12.13 \mathrm{a}$ & $2.10 \mathrm{a}$ & $3.70 \mathrm{a}$ \\
Growth & $4.10 \mathrm{a}$ & $11.90 \mathrm{~b}$ & $15.5 \mathrm{a}$ & $12.30 \mathrm{a}$ & $5.80 \mathrm{a}$ & $6.00 \mathrm{a}$ \\
\hline
\end{tabular}

Values in the same column followed by distinct letters differ at the $5 \%$ level of significance by the one-way ANOVA test.

Table 7 - Frequency of Nymphicus hollandicus visits to feeders, followed by standard deviation, by different stages of development

\begin{tabular}{ccccccc}
\hline & Rice & Millet & Oat & Sun flower & Farinhada & Ration \\
\hline R & $0.84 \pm 0.98 \mathrm{a}$ & $0.58 \pm 0.70 \mathrm{a}$ & $0.42 \pm 0.62 \mathrm{a}$ & $0.56 \pm 0.65 \mathrm{a}$ & $1.64 \pm 0.67 \mathrm{a}$ & $1.13 \pm 0.34 \mathrm{~b}$ \\
M & $0.91 \pm 1.29 \mathrm{a}$ & $0.60 \pm 0.75 \mathrm{a}$ & $0.80 \pm 0.80 \mathrm{~b}$ & $0.93 \pm 1.22 \mathrm{a}$ & $1.00 \pm 0.45 \mathrm{a}$ & $0.63 \pm 0.50 \mathrm{a}$ \\
$\mathrm{G}$ & $1.78 \pm 1.00 \mathrm{~b}$ & $1.62 \pm 0.84 \mathrm{~b}$ & $1.92 \pm 1.03 \mathrm{~b}$ & $1.69 \pm 0.79 \mathrm{~b}$ & $1.27 \pm 0.90 \mathrm{a}$ & $0.81 \pm 0.75 \mathrm{~b}$ \\
\hline
\end{tabular}

Values in the same column followed by distinct letters differ the level of significance by $5 \%$ by the one-way ANOVA test. $\mathrm{R}=$ reproduction; $\mathrm{M}=$ maintenance; $\mathrm{G}=$ growth.

Table 8 - Mean of visits of Nymphicus hollandicus to the locations inside the cage by the birds of the different stages, followed by the corresponding standard deviation

\begin{tabular}{cccc}
\hline Location & Reproduction & Maintenance & Growth \\
\hline Door grid & $0.27 \pm 0.47 \mathrm{a}$ & $1.45 \pm 0.82 \mathrm{a}$ & $1.18 \pm 0.75 \mathrm{~b}$ \\
Nest grid & $1.50 \pm 0.71 \mathrm{~b}$ & $0.00 \pm 0.00 \mathrm{a}$ & $0.00 \pm 0.00 \mathrm{a}$ \\
Partition grid & $0.53 \pm 0.70 \mathrm{a}$ & $1.63 \pm 0.90 \mathrm{~b}$ & $0.37 \pm 0.76 \mathrm{~b}$ \\
Top grid & $0.00 \pm 0.00 \mathrm{a}$ & $0.50 \pm 071 \mathrm{a}$ & $1.00 \pm 0.00 \mathrm{~b}$ \\
Rear grid & $0.22 \pm 0.44 \mathrm{a}$ & $1.78 \pm 0.67 \mathrm{~b}$ & $0.22 \pm 0.44 \mathrm{a}$ \\
Floor & $1.53 \pm 0.62 \mathrm{a}$ & $0.71 \pm 0.69 \mathrm{~b}$ & $2.00 \pm 1.32 \mathrm{~b}$ \\
Upper perch & $2.97 \pm 2.32 \mathrm{a}$ & $2.82 \pm 2.10 \mathrm{a}$ & $2.85 \pm 2.63 \mathrm{a}$ \\
Lower perch & $3.74 \pm 2.05 \mathrm{a}$ & $3.32 \pm 2.64 \mathrm{a}$ & $2.85 \pm 2.13 \mathrm{a}$ \\
Nest & $1.41 \pm 0.73 \mathrm{a}$ & $0.86 \pm 0.82 \mathrm{~b}$ & $0.52 \pm 0.70 \mathrm{~b}$ \\
Ration feeder & $1.13 \pm 0.34 \mathrm{~b}$ & $0.63 \pm 0.50 \mathrm{a}$ & $0.81 \pm 0.75 \mathrm{a}$ \\
Farinhada feeder & $1.64 \pm 0.67 \mathrm{a}$ & $1.00 \pm 0.45 \mathrm{a}$ & $1.27 \pm 0.90 \mathrm{a}$ \\
Oat feeder & $0.42 \pm 0.62 \mathrm{a}$ & $0.80 \pm 0.80 \mathrm{~b}$ & $1.92 \pm 1.03 \mathrm{~b}$ \\
Rice feeder & $0.84 \pm 0.98 \mathrm{a}$ & $0.91 \pm 1.29 \mathrm{a}$ & $1.78 \pm 1.00 \mathrm{~b}$ \\
Sunflower feeder & $0.56 \pm 0.65 \mathrm{a}$ & $0.93 \pm 1.22 \mathrm{a}$ & $1.69 \pm 0.79 \mathrm{~b}$ \\
Millet feeder & $0.58 \pm 0.70 \mathrm{a}$ & $0.60 \pm 0.75 \mathrm{a}$ & $1.62 \pm 0.84 \mathrm{~b}$ \\
Water drinker & $0.80 \pm 0.60 \mathrm{ao}$ & $1.10 \pm 0.32 \mathrm{a}$ & $1.10 \pm 0.74 \mathrm{a}$ \\
Calcium & $0.30 \pm 0.48 \mathrm{a}$ & $1.00 \pm 0.00 \mathrm{~b}$ & $0.90 \pm 0.32 \mathrm{~b}$ \\
\hline
\end{tabular}

Values on the same line followed by distinct letters differ the $5 \%$ level of significance by the one-way ANOVA test.

the birds at the reproduction stage, a fact already expected, as the grid is attached to the nest, serving as a passage and observation place. The nest was also most visited at this stage for preparation, laying, and neonatal care.

\section{Discussion}

The environment temperature of $29^{\circ} \mathrm{C}$ is within the thermal comfort of the species Nymphicus hollandicus. Carvalho (2014) observed an increase in the consumption of cockatiel food when the environment temperature reached $35^{\circ} \mathrm{C}$.

The cockatiel females at the growth stage displayed a statistically significant growth. Ubuka \& Bentley (2011) observed that younger animals grow more than adult animals.

There was no significant variation in the consumption of foods such as rice, oats, sunflower seeds, farinhada, and ration, although the consumption values of oats were $56 \%$ higher in the cockatiels of the growth stage. Saad et al. (2007) observed an oat digestibility of 75\% for true parrots (Amazona aestiva). There was a statistically significant increase in visits to the millet feeder, and millet consumption, by the cockatiels in the growth stage. Earle \& Clarke (1991) observed that the apparent digestibility of millet protein by parakeets ranged from 72 to $91 \%$. This corroborates the results of the present study, with a significant increase in the frequency of visits to the feeder for millet and oat. The preference of young individuals for oats was due to palatability, high protein content, or even the yellowish color of the oats (Cubas et al., 2014). Carciofi et al. (2006) observed a higher consumption of millet for birds of the species A. auricapilla.

Seeds are generally the first choice of birds, because they are quite palatable and, in the case of granivorous birds, such as cockatiels, they resemble the food of natural habitats (Koutsos et al., 2001a). Based on the data obtained in this study, it can be inferred that millet and oat foods have greater importance in the growth of young cockatiels. The significant increase in the frequency of visits to the rice, sunflower, and ration feeders did not reflect the increase in consumption of these foods.

From the location analysis in the cage, we verified that the birds in the reproduction stage frequented the door grid fewer times $(\mathrm{p}<0.05)$ compared to the birds in other stages of development. Likewise, they obtained a lower frequency of visits to the partition grid and the upper grid. The nest grid was visited more frequently by the birds of the reproduction stage, a fact already expected as the grid is attached to the nest, serving as a passageway and a place of watch. The nest was also more visited at the reproduction stage for preparation, posture, and neonatal care, as observed by Locatelli et al. (2013) in pairs of macaws Canindé (Ara ararauna), where the male visits the nests to feed the young and/or the female. 
The birds in all stages showed a preference for the perches, among all the locations. In the growth stage, the frequency of visits to the upper perch and the floor was higher than in the other stages, since cockatiels have the habit of performing their feeding on the ground and young birds tend to be more active and consume more food (Torloni, 2001).

\section{Conclusion}

The conclusion obtained in this study was that young cockatiels have a preference for millet and oats. Adult cockatiels prefer ration. All the birds showed a preference for the "PULEIRO" in all the stages of development. The birds in the reproduction stage were the ones that visited the nest, and the nest grid, the most.

\section{References}

Altmann J. Observational study of behavior: sampling methods. Behaviour. 1974;49(3-4):227-66. http://dx.doi. org/10.1163/156853974X00534. PMid:4597405.

Carciofi AC. Contribuição ao estudo da alimentação da arara-azul (Anodorhynchus hyacinthinus, Psittacidae, aves) no Pantanal, I Análise da química do acuri (Scheelea phalerata) e da bocaiuva (Acronimia aculeata), II - Aplicabilidade do método de indicadores naturais para o cálculo da digestibilidade, III - Energia metabolizável e ingestão de alimentos [tese]. São Paulo: Universidade de São Paulo; 2000.

Carciofi AC, Prada CS, Mori CS. Evaluation of fruit-seed based diets for parrots (Amazona sp.): I- determination of food selection and nutritional composition. Ars Vet. 2003;19:13-20.

Carciofi AC, Saad CEP. Nutrition and nutritional problems in wild animal In: Fowler ME, Cubas ZS, editors. Biology, medicine, and surgery of South American Wild Animals. Ames: Iowa State University Press; 2001. p. 425-34. http:// dx.doi.org/10.1002/9780470376980.ch36.

Carciofi AC, Duarte JM, Mendes D, Oliveira LD. Food selection and digestibility in yellow-headed conure (Aratinga jandaya) and golden-capped conure (Aratinga auricapilla) in captivity. J Nutr. 2006;2006(136):2014S-6S.

Carvalho TSG. Comportamento de calopsitas (Nymphicus hollandicus) mantidas em cativeiro sob duas temperaturas e enriquecimento ambiental [dissertação]. Lavras: Universidade Federal de Lavras; 2014.

\section{Conflict of Interest}

The authors declare no conflict of interests in the current manuscript.

\section{Ethics Statement}

This research was carried out in a Ibama authorization number 9999.7575 / 2013-DF.

\section{Acknowledgements}

To Vanair Carlos Paz and his family for making their breeder and animals available to the research team and assisting in the development of the study. To Professor Pedro Felipe Vieira Gomides for making himself available to analyze the foods offered in this study, at the UPIS Food Analysis Laboratory.

Cubas ZS, Silva JCR, Catão-Dias JL, editors. Tratado de animais selvagens. 2. ed. São Paulo: Roca; 2014. p. 613-9. (vol. 1).

Earle KE, Clarke NR. The nutrition of the budgerigar (Melopsittacus undulatus). J Nutr. 1991;121(11, Suppl):S186-92. http://dx.doi.org/10.1093/jn/121.suppl_11.S186. PMid:1941225.

Forshaw JM. Parrots of the World. Austrália: T.F.H. Publications; 1973.

Forshaw JM. Parrots of the World. Princeton: Princeton University Press; 2010. 328 p. http://dx.doi.org/10.1515/9781400836208.

Hammer $\varnothing$, Harper DAT. PAST: paleontological statistics software package for education and data analysis. Palaeontol Electronica. 2001;4(1):9.

Harcourt-Brown NH. Psittacine birds. In Tully TN, Lawton MPC, Dorrestein GM, editors. Avian medicine. New York: Elsevier; 2003. p. 114-5.

Harper EJ, Skinner ND. Clinical nutrition of small psittacines and passerines. J Exot Pet Med. 1998;7(3):116-27. http:// dx.doi.org/10.1016/S1055-937X(98)80002-9.

Koutsos EA, Matson KD, Klasing KC. Nutrition of birds in the order psittaciformes: a review. J Avian Med Surg. 2001a;15(4):257-75. http://dx.doi.org/10.1647/10826742(2001)015[0257:NOBITO]2.0.CO;2. 
Koutsos EA, Smith J, Woods LW, Klasing KC. Adult cockatiels (Nymphicus hollandicus) metabolically adapt to high protein diets. J Nutr. 2001b;131(7):2014-20. http:// dx.doi.org/10.1093/jn/131.7.2014.

Locatelli AC, Wrublack SC, Basile LF, Nascimento AF, Berber GCM, Berber RCA. Comportamento reprodutivo e materno de araras Canindé (Ara ararauna) mantidas em cativeiro para conservação. Comun Sci. 2013;4(4):316-23.

Machado PAR, Saad CEP. O futuro das rações para aves ornamentais e silvestres no Brasil. Rev Sul Americana de Ornitofilia. 2000;3:37-40.

Martins JS, Paz V, Navarro RD. Homeopatia e suplemento alimentar no crescimento de filhotes de periquito australiano (Melopsittacus undulatus). Braz J Sustainable Agriculture. 2019;9:82-8. http://dx.doi.org/10.21206/rbas.v9i04.8066.

Mendes D. Seletividade e digestibilidade em Aratinga jandaya e Aratinga auricapillasob condições de cativeiro [trabalho de graduação]. Jaboticabal: Faculdade de Ciências Agrárias e Veterinárias, Universidade Estadual Paulista; 1999.

Morton RS. Granivory in arid regions: comparison of Australia with North and South America. Ecology. 1985;66(6):185966. http://dx.doi.org/10.2307/2937381.
Roudybush TE, Grau CR. Food and water interralations and the protein requirement for growth of an Altricial Bird, the Cockatiel (Nymphicus hollandicus). J Nutr. 1986;116(4):5529. http://dx.doi.org/10.1093/jn/116.4.552. PMid:3958803.

Saad CEP, Ferreira WM, Borges FMO, Lara LB. Avaliação do gasto e consumo voluntário de rações balanceadas e semente de girassol para papagaios verdadeiros (Amazona aestiva). Cienc Agrotec. 2007;31(4):1176-83. http://dx.doi. org/10.1590/S1413-70542007000400034.

Silva DJ. Análise de alimentos: métodos químicos e biológicos. 2. ed. Viçosa: UFV; 1990. 165 p.

Torloni CEC. Criação de calopsitas. São Paulo: Lis; 2001.80 p.

Ubuka T, Bentley GE. Neuroendocrine control of reproduction in birds. In: Norris DO, Lopez KH, editors. Hormones and reproduction of vertebrates in birds. Amsterdam: Elsevier; 2011.p. 1-25.

Financial support: None. 